
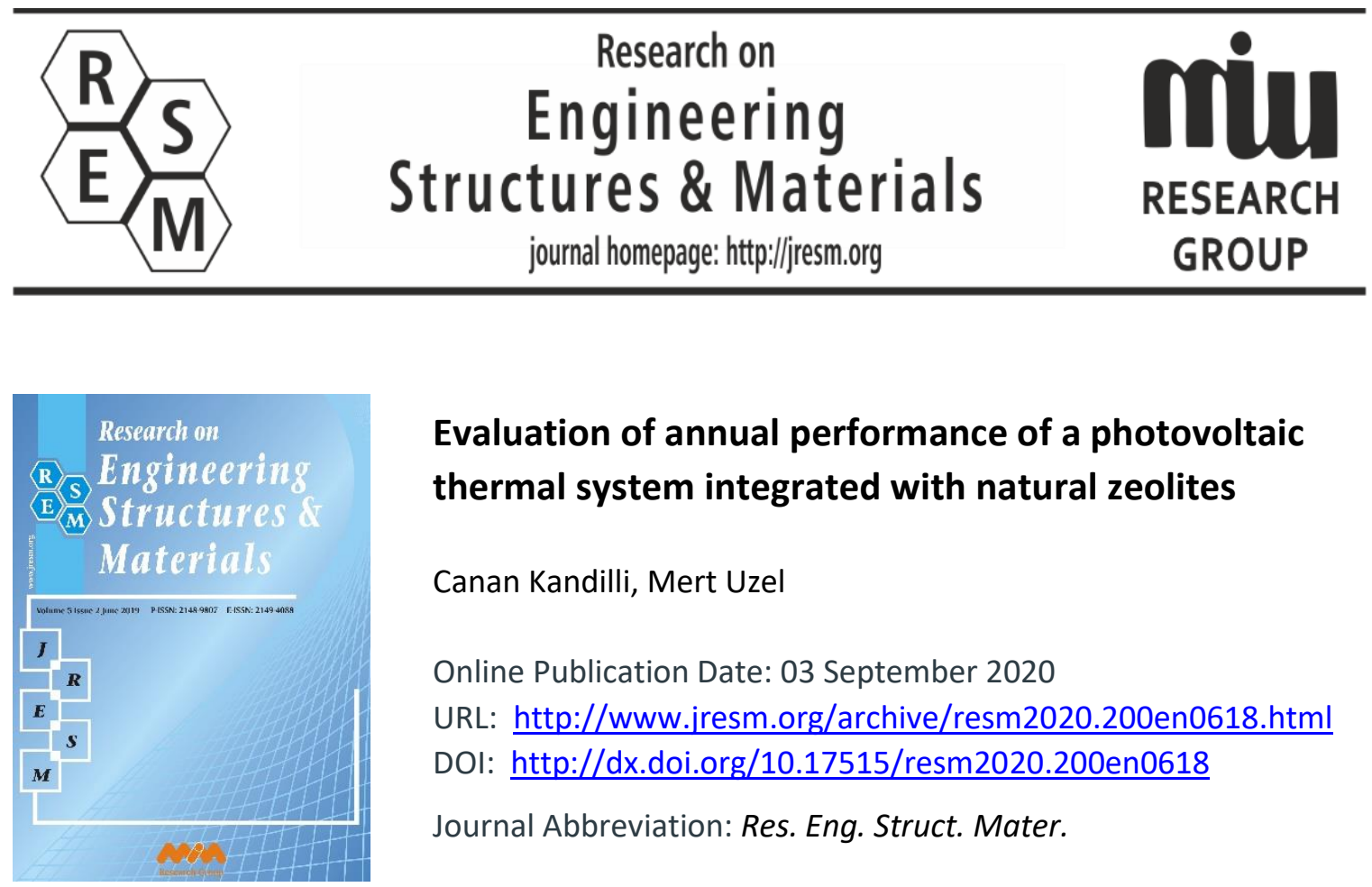

\title{
Evaluation of annual performance of a photovoltaic thermal system integrated with natural zeolites
}

Canan Kandilli, Mert Uzel

Online Publication Date: 03 September 2020

URL: http://www.jresm.org/archive/resm2020.200en0618.html

DOI: http://dx.doi.org/10.17515/resm2020.200en0618

Journal Abbreviation: Res. Eng. Struct. Mater.

\section{To cite this article}

Kandilli C, Uzel M. Evaluation of annual performance of a photovoltaic thermal system integrated with natural zeolites. Res. Eng. Struct. Mater., 2020; 6(4): 363-374.

\section{Disclaimer}

All the opinions and statements expressed in the papers are on the responsibility of author(s) and are not to be regarded as those of the journal of Research on Engineering Structures and Materials (RESM) organization or related parties. The publishers make no warranty, explicit or implied, or make any representation with respect to the contents of any article will be complete or accurate or up to date. The accuracy of any instructions, equations, or other information should be independently verified. The publisher and related parties shall not be liable for any loss, actions, claims, proceedings, demand or costs or damages whatsoever or howsoever caused arising directly or indirectly in connection with use of the information given in the journal or related means.

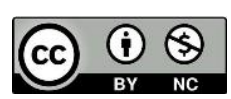

Published articles are freely available to users under the terms of Creative Commons Attribution - NonCommercial 4.0 International Public License, as currently displayed at here (the "CC BY - NC"). 


\title{
Research on Engineering Structures \& Materials \\ journal homepage: http://jresm.org
}

Research Article

\section{Evaluation of annual performance of a photovoltaic thermal system integrated with natural zeolites}

\author{
Canan Kandilli* (Ph.D), Mert Uzel
}

Department of Mechanical Engineering, Usak University, Usak, Turkey

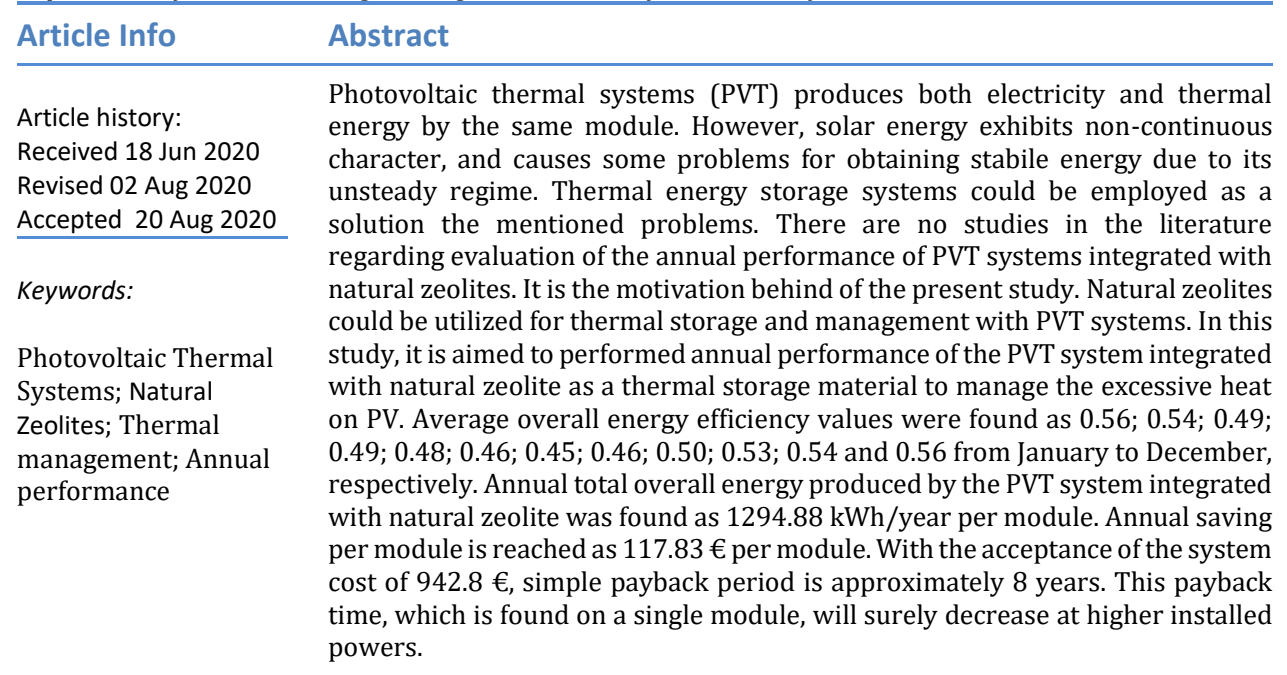

(c) 2020 MIM Research Group. All rights reserved.

\section{Introduction}

For crystalline silicon photovoltaic (PV) cells, a drop in the electrical power output of about $0.2-0.5 \%$ was reported for every $1^{\circ} \mathrm{C}$ rise in the PV module temperature principally due to the temperature dependence of the open-circuit voltage of the cell depending on the PV technology [1]. Photovoltaic Thermal System (PVT) presents a useful solution to overcome the excessive heat on PV surface [2]. During the melting or solidification processes, a Phase Change Material (PCM) can store or release a large amount of latent heat. The temperature of the PCM can be maintained during the latent heat transfer process. Therefore, PCM is a very promising material for energy storage and for controlling the thermal environment. In the last decades, there are numerous studies on PVT systems integrated with PCM have been carried out in the literature [3-10].

However, PCMs have many disadvantages in practice and natural zeolite for PVT system as a heat storage material to manage excessive heat has been newly proposed [11]. As known, PCMs are the first material that comes to mind to provide more thermal energy in PVTs. However, it is a critical advantage that natural zeolite has almost free, very affordable cost. On the other hand, PCMs significantly increases PVT costs. Another issue is ease of application. Natural zeolite can be easily integrated into PVTs than PCMs. In order to use paraffin, it is necessary to melt, split or apply as microcapsules. It is also necessary to

\footnotetext{
*Corresponding author: canan.kandilli@usak.edu.tr aorcid.org/0000-0001-7159-4174 
quickly remove paraffin from the PVT system when it is hot. High cost, harmful to health and risk of leakage make PCMs disadvantageous. On the other hand, natural zeolites are superior to PCMs in terms of human health in terms of both antibacterial structure and lack of harmful chemicals.

Zeolite is a porous crystalline hydrated aluminosilicate with a cage-like structure. Its framework structure encloses cavities occupied by water molecules and cations which can move freely permitting reversible dehydration and ion exchange. There are more than 40 types natural zeolites while synthesized zeolites have more than 150 types [12]. 75\% of natural zeolite reserve takes place in Turkey, half of the reserved in Turkey are in Gordes. Other significant zeolite deposits in Turkey Ankara, Kütahya, Manisa, İzmir, Balıkesir and is located in Cappadocia. The main physical and chemical properties of zeolites are; the ability to make ion exchanges, adsorption and molecular sieve structure, silica content, as well as being light colored in sedimentary zeolites, lightness, pore structure of small crystals caused zeolites to be used in a wide variety of industrial areas. Usage areas of one or more of these properties of natural zeolites which have become an important industrial raw material in recent years are Pollution Control; Mining and Metallurgy; paper, building, health and chemistry sectors [13] In the literature, PVTs have been integrated with PCMs so far. Natural zeolites have many advantages over PCMs. In this study, natural zeolites are recommended for thermal management and heat storage of PVTs. Moreover, in the efficiency calculations in the study, the stored thermal energy that the zeolite will provide to the system after the sunset is not taken into consideration. Considering the stored temperature, the integration of zeolites with PVT is a remarkable alternative.

In this study, annual performance of the PVT system integrated with natural zeolite to control the excessive heat on PV module has been evaluated. There is no study on the annual performance of the natural zeolite based PVT system in the literature. It is the motivation of the present study. However, some studies on annual performance of PVT systems could be found in the literature. Brottier and Bennacer performed a statistical study was realized to analyze in-field performances of twenty-eight hybrid solar domestic hot water installations equipped with innovative non-overglazed PVT collectors in Western Europe. They showed that PVT technology, more than PV production, is particularly relevant on domestic hot water preheating, with a monthly average of daily maximal temperature in the panels reaching above $45^{\circ} \mathrm{C}$ during 5 months in the year [14]. Ji et al. established a mathematical model, verified by experimentally, evaluated annual performance and investigated aspect ratio of a building integrated PV system (BIPV) to analyze seasonal energy demand of four cities of China [15]. Gholami and Røstvik presented BIPV as a building envelope material for the whole building skins, performed economic analyses of a BIPV system in 30 countries. They emphasized that even the north facade is economically feasible in some countries in Europe if all the environmental and societal benefits of the BIPV system are being taken into consideration [16].

In the present study, it is aimed to performed annual performance of the PVT system integrated with natural zeolite as a thermal storage material to manage the excessive heat on PV. There are no studies in the literature regarding evaluation of the annual performance of PVT systems integrated with natural zeolites. It is the motivation behind of the present study. Firstly, mathematical models were derived by experimental data and solar irradiance values. These models were employed to estimate monthly average hourly values of overall energy efficiency, produced electrical power, overall produced energy and savings by PVT system based on natural zeolites. Estimated parameters were calculated depending on solar irradiance data that found by taking the average of 8-year hourly data. Evaluation of annual performance of the PVT integrated with natural zeolites is firstly presented in the open literature. 


\section{System Description}

It is very important to analyze the energy systems thermodynamically to determine system efficiency. For this aim, the following assumptions have been considered:

- $\quad$ PV surface temperature is assumed as a constant through the PV module.

- The system is assumed as steady-state open system.

- Inner surface of fluid channel is smooth.

- The thermal resistance of the fluid channel and radiation losses is ignored.

- Atmospheric pressure is assumed as $\mathrm{P}_{0}=1 \mathrm{~atm}$.

- The heat losses for the bottom and the edge surface of the PVT could be ignored due to the insulation layer.

- The dead state temperature is assumed as equal to the ambient temperature.

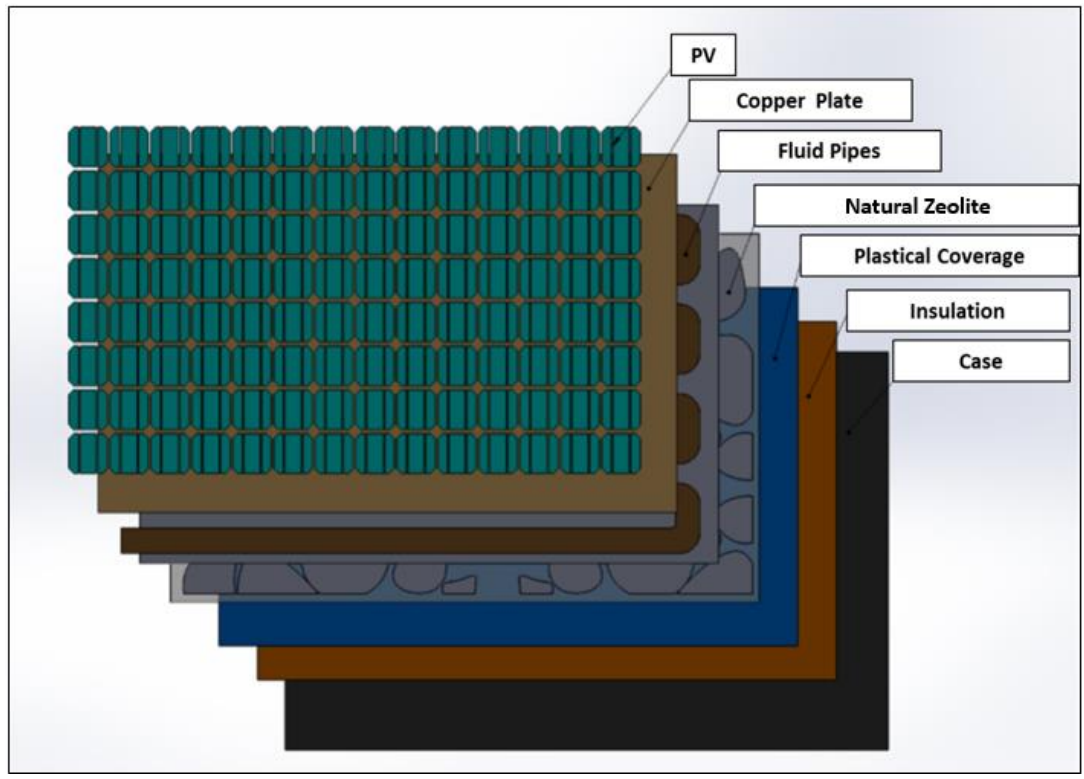

Fig 1. Diagram of the layers of PVT-Zeolite system.

The layers of PVT system integrated with natural zeolite are shown in Fig.1 for the present study. Solar radiation, which cannot be converted into electricity by solar cells, creates an excessive heat on PV. This excessive heat is removed by the working fluid and is stored as sensible heat in the zeolite layer. Thus, the stored heat energy will continue to provide thermal energy at times when solar energy is not sufficient or after the sun goes down. Furthermore, the heat load on the PV will also be removed and the electrical efficiency will be reduced. Energy analysis of the PVT systems based on natural zeolite has been reported in detail before [11]. For this reason, a short reminder about the parameters used in this study will be made.

$$
\dot{\mathrm{Q}}_{\text {thermal }}=\dot{\mathrm{m}}_{\mathrm{P}}\left(\mathrm{T}_{\text {out }}-\mathrm{T}_{\text {in }}\right)
$$

In the above equation, $\dot{\mathrm{Q}}_{\text {thermal }}$ is the useful power $(\mathrm{W}), \dot{\mathrm{m}}$ is mass flow rate of working fluid, $\mathrm{T}_{\text {in }}$ and $\mathrm{T}_{\text {out }}$ are inlet and outlet temperatures and $\mathrm{C}_{\mathrm{P}}$ is specific heat respectively. 
The thermal $\left(\eta_{\text {thermal }}\right)$ and electrical efficiency $\left(\eta_{\mathrm{PV}}\right)$ of the PVT system could be defined as below, respectively:

$$
\begin{aligned}
& \eta_{\text {thermal }}=\frac{\dot{\mathrm{Q}}_{\text {thermal }}}{\mathrm{I} \times \mathrm{A}_{\mathrm{C}}} \\
& \eta_{\mathrm{PV}}=\frac{\dot{\mathrm{W}}_{\mathrm{PV}}}{\mathrm{I} \times \mathrm{A}_{\mathrm{C}}} \\
& \dot{\mathrm{W}}_{\mathrm{PV}}=I . V
\end{aligned}
$$

Electrical power is the product of voltage and current obtained from PV. Overall power is the sum of thermal and electrical power:

$$
\dot{\mathrm{Q}}_{\text {overall }}=\dot{\mathrm{Q}}_{\text {thermal }}+\dot{\mathrm{W}}_{\mathrm{PV}}
$$

\section{Results}

The aim of this study is to reveal the annual performance evaluation in the light of the data obtained from PVT systems based on natural zeolite. First of all, the statistical relationships between solar irradiance and electrical power, overall energy efficiency and produced overall energy have been presented. The mathematical models were derived from these relationships to estimate annual values by using solar irradiance data in hourly basis. Electrical power, overall system energy efficiency and produced overall power values were hourly calculated by these models for whole year. Then, for all these parameters, monthly average hourly values were reached. Monthly savings from the PVT systems integrated with natural zeolite has been calculated.

In the present study, global solar irradiance, ambient temperature and wind speed data have been obtained by the meteorology station (Davis Vantage Pro2) established on the terrace of the building of Department of Mechanical Engineering. These meteorological data has been recorded since 2011. Usak, as a small Anatolian province, is located at a latitude of $38.41^{\circ} \mathrm{N}$, longitude of $29.25^{\circ} \mathrm{E}$ and altitude of $906 \mathrm{~m}$. Usak, located in the transition region from Mediterranean climate belt to continental climate condition, has hot and dry summers and long cold winters.

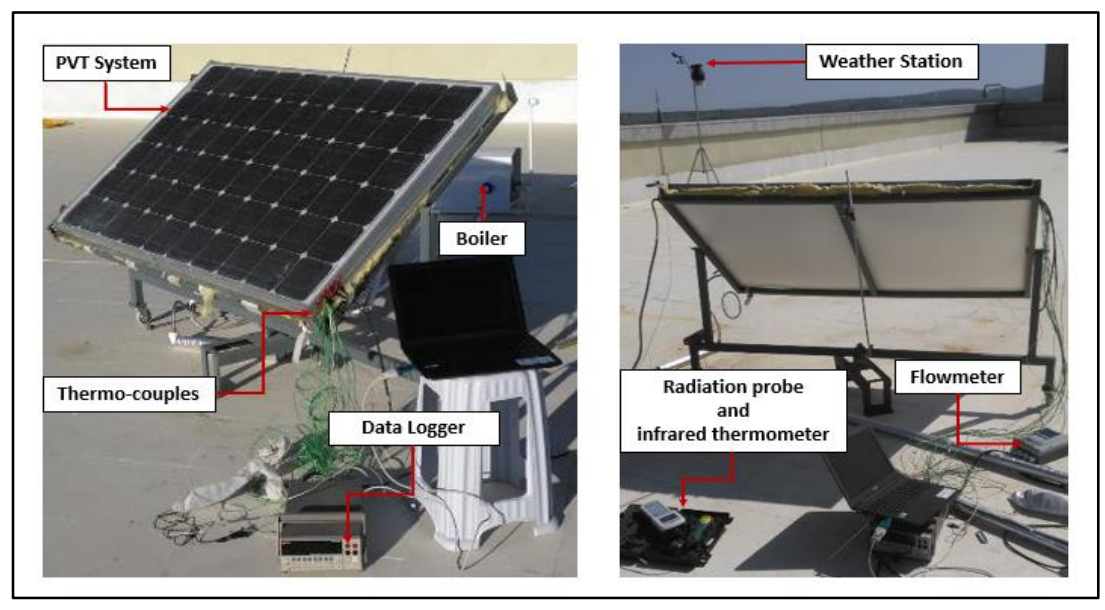


Fig 2. PVT test system based on natural zeolites and measuring devices.

PVT test system based on natural zeolites and measuring devices are presented by Fig. 2 . The PVT experiments were carried out on the roof of the Usak University Mechanical Engineering Building on April, May and June 2016 under different meteorological conditions. In natural zeolite PVT system experiments operating naturally under a flow of $18 \mathrm{l} / \mathrm{h}$, inlet and outlet temperatures, surface temperatures and surface solar radiation, flow and meteorological data were measured, uncertainties and theoretical analysis were presented in previous studies [11]. Figures 3-5 present the statistical relationships between overall energy efficiency, electrical power (W) and overall power (W) that is sum of thermal and electrical power produced by PVT system and solar irradiance on PVT surface. Determination coefficients were found as $0.9543 ; 0.9294$ and 0.9254 for the relations between overall energy efficiency, electrical power and overall power and solar radiation on PVT surface. Derived models by these statistical relationships were employed to calculate the monthly average of hourly values of overall energy efficiency, electrical power, and overall power for a whole year. Hourly solar radiation data required to make calculations. By using these parameters models were calculated using 8-year solar radiation data obtained from the weather station. As it is known, weather station measures the global solar radiation on horizontal surface. However, the PVT system in this study was directed to the south and a $38^{\circ}$ tilt angle was given. The hourly solar radiation data received from the meteorology station was directed to the south and the solar radiation coming to the $38^{\circ}$ inclined panel was calculated hourly. Detailed information on the calculation of solar radiation on the inclined surface is available in the basic literature [15]. As a result, based on the experimental models, annual total energy efficiency, electrical power and total power calculations were made for PVT with solar radiation data on an hourly basis. The results for these calculations are presented below.

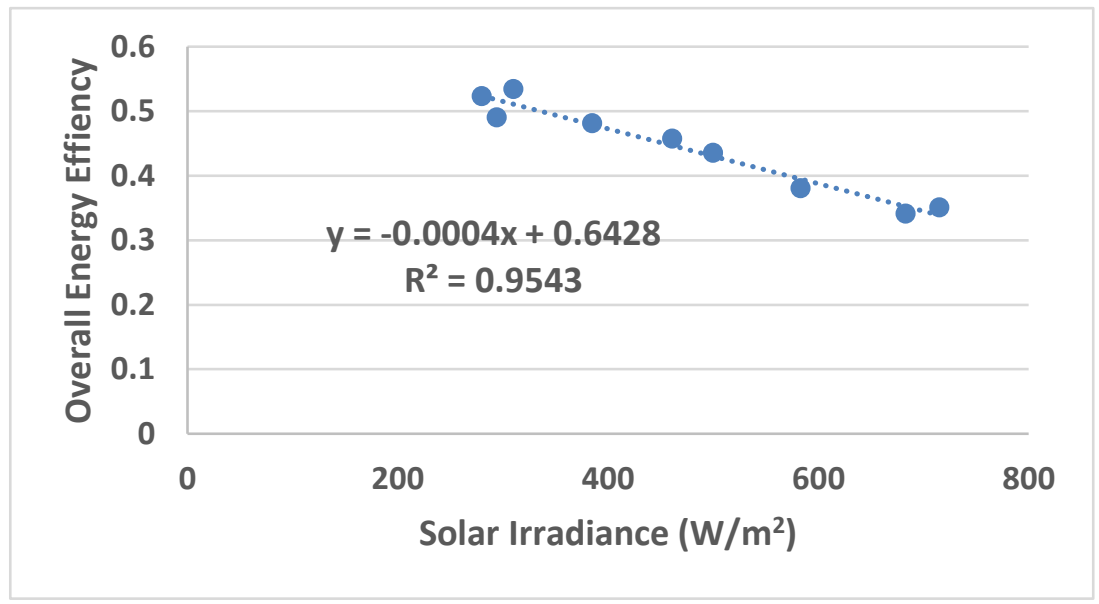

Fig 3. Statistical relationship between overall energy efficiency of the PVT system and solar irradiation $\left(\mathrm{W} / \mathrm{m}^{2}\right)$ 


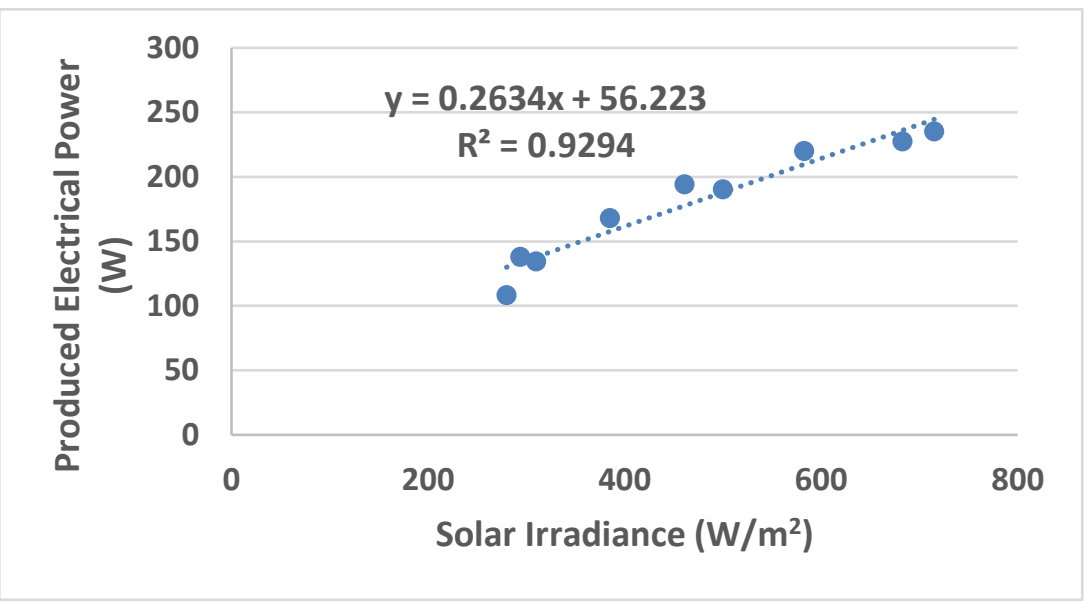

Fig 4. Statistical relationship between electrical power produced by the PVT system and solar irradiation $\left(\mathrm{W} / \mathrm{m}^{2}\right)$

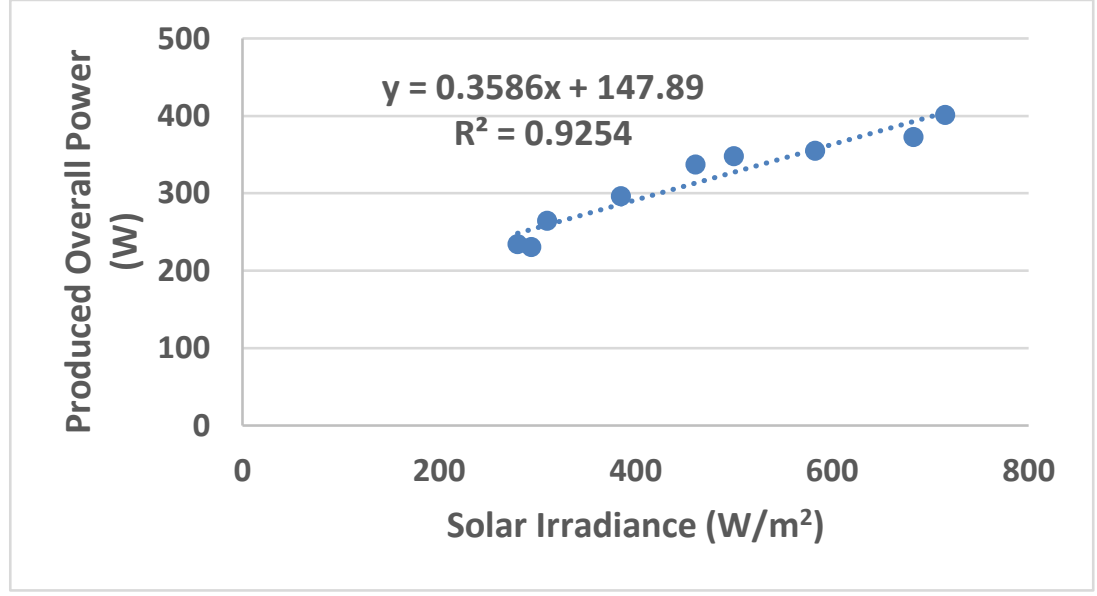

Fig 5. Statistical relationship between overall power produced by the PVT system and solar irradiation $\left(\mathrm{W} / \mathrm{m}^{2}\right)$ 


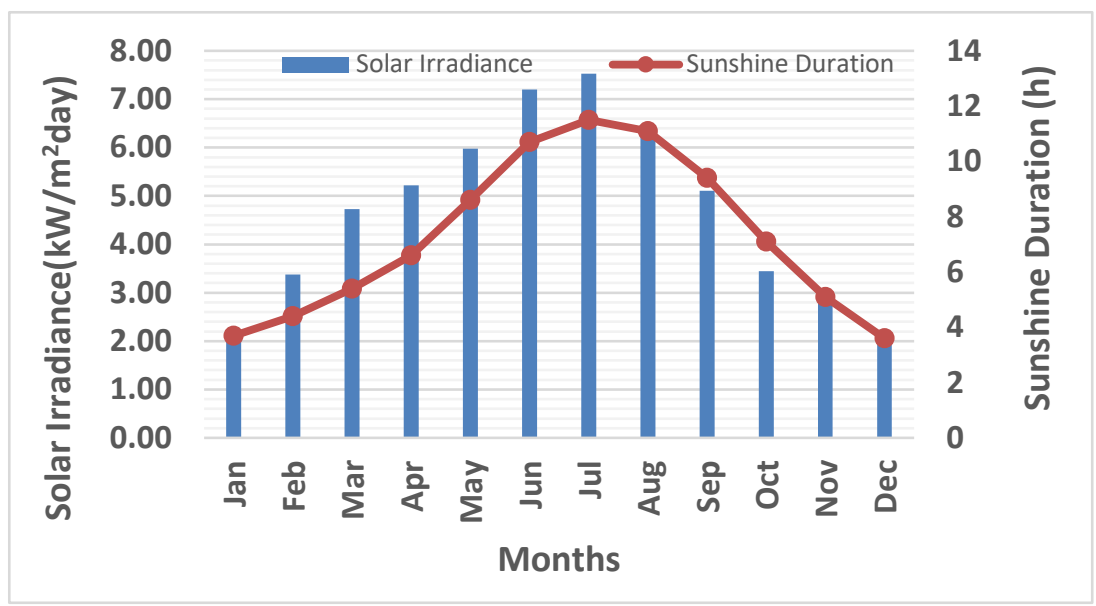

Fig 6. Monthly variation of average daily solar irradiance $\left(\mathrm{kW} / \mathrm{m}^{2} \mathrm{day}\right)$ and sunshine duration $(\mathrm{h})$

Variation of monthly variation of average daily solar irradiance $\left(\mathrm{kW} / \mathrm{m}^{2} \mathrm{day}\right)$ and sunshine duration (h) were plotted in Fig. 6. To calculate monthly variation of average daily solar irradiance, for all days of the month in question, the average of the data at a certain hour is taken. For example, for all days of January (Jan 1-31), all irradiation values in each hour are summed and divided by 31 , the number of days per month. Thus, hourly values that characterize the relevant month were obtained. For each calculation, 8760 solar radiation data were used. Monthly variation of average daily solar irradiance values were found as $2.11 ; 3.38 ; 4.73 ; 5.22 ; 5.98 ; 7.20 ; 7.53 ; 6.44 ; 5.11 ; 3.44 ; 2.85 ; 2.13$ from January to December, respectively. One of the important data in energy calculations produced from photovoltaic panels is sunshine duration. Monthly average sunshine duration values for Usak Province were also given by Fig.6. That is listed as 3.7; 4.4; 5.4; 6.6; 8.6; 10.7; 11.5; $11.1 ; 9.4 ; 7.1 ; 5.1$ and 3.6 hours for January to December, respectively [18]. Yearly average sunshine duration is 7.3 hours/day for the study location. As expected, the total solar radiation increases as the sunshine duration increases. Surely, the main purpose in providing this information is to show under which solar radiation conditions performance evaluations are obtained. 


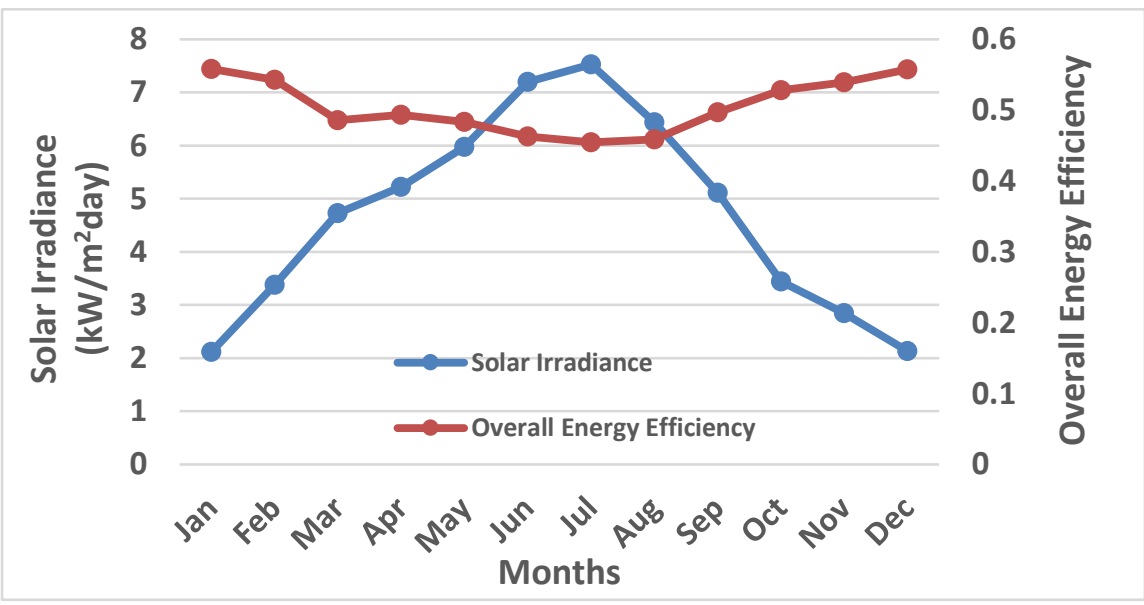

Fig 7. Monthly variation of overall energy efficiency against average daily solar irradiance $\left(\mathrm{kW} / \mathrm{m}^{2} \mathrm{day}\right)$

Fig 7 gives monthly variation of overall energy efficiency against average daily solar irradiance $\left(\mathrm{kW} / \mathrm{m}^{2} \mathrm{day}\right)$. Average overall energy efficiency values were found as $0.56 ; 0.54$; $0.49 ; 0.49 ; 0.48 ; 0.46 ; 0.45 ; 0.46 ; 0.50 ; 0.53 ; 0.54$ and 0.56 from January to December, respectively. As with all thermal collectors, the efficiency of the system decreases as the solar radiation increases.

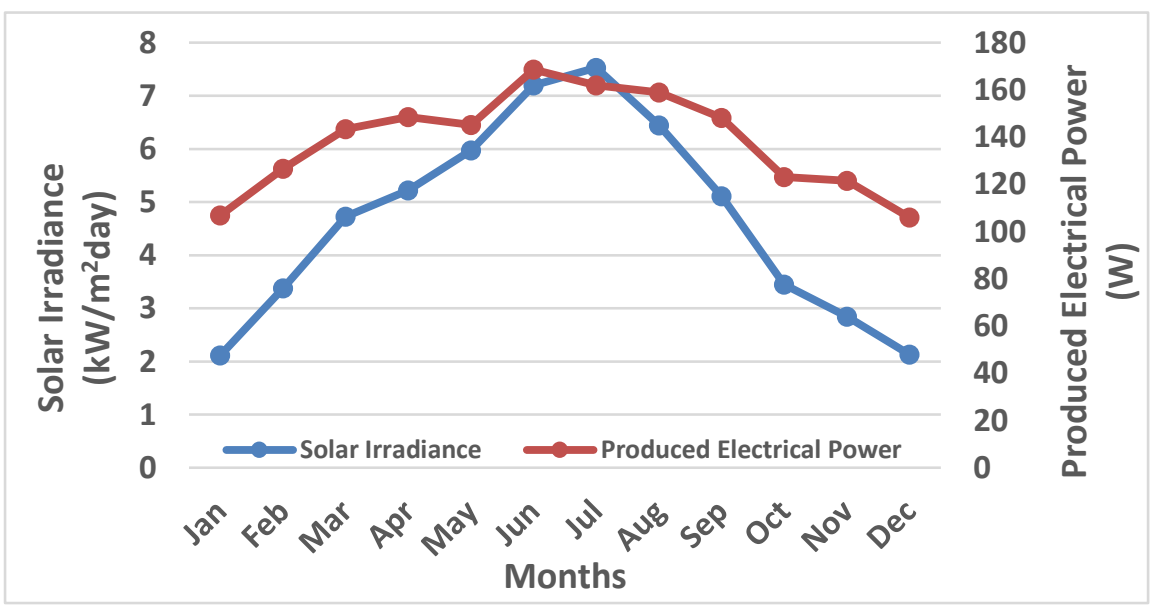

Fig 8. Monthly variation of produced electrical power (W) against average daily solar irradiance $\left(\mathrm{kW} / \mathrm{m}^{2}\right.$ day)

Monthly variation of produced electrical power and monthly variation of overall produced energy (kWh) by solar irradiance are given by Fig.8 and Fig.9. As the solar radiation increases, the electrical power produced and the overall energy increase. Monthly average hourly produced electrical power values per module were calculated as 106.8; 126.7; 
$143.4 ; 148.5 ; 145.2 ; 168.6 ; 161.9 ; 158.9 ; 148.2 ; 123.0 ; 121.4$ and $105.9 \mathrm{~W}$ from January to December, respectively. Similarly, monthly average overall produced energy values $(\mathrm{kWh})$ were determined as 73.93; 85.39; 105.59; 117.66; 131.15; 148.04; 151.35; 131.67; 117.50; 87.12; 79.90 and 65.59 from January to December, respectively. After calculating the hourly average values representing all the days of that month for each month, the daily total values were found, multiplied by the number of days in the relevant month, so the monthly average total produced energy was calculated. Annual total overall energy produced by the PVT system integrated with natural zeolite was found as 1294.88 $\mathrm{kWh} /$ year per module.

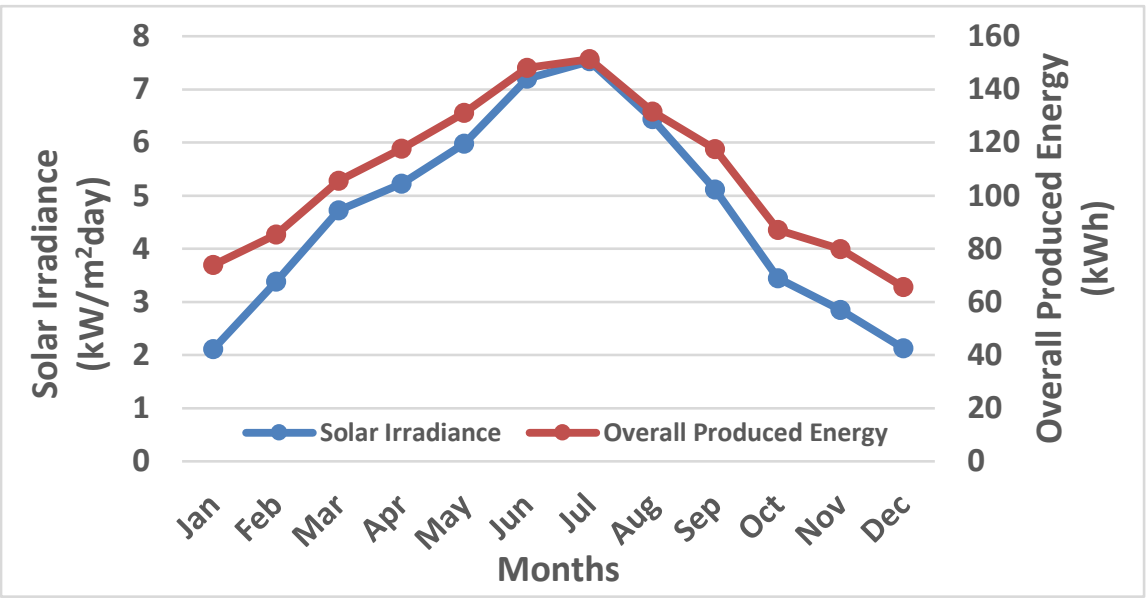

Fig 9. Monthly variation of overall produced energy $(\mathrm{kWh})$ against average daily solar irradiance $\left(\mathrm{kW} / \mathrm{m}^{2}\right.$ day $)$

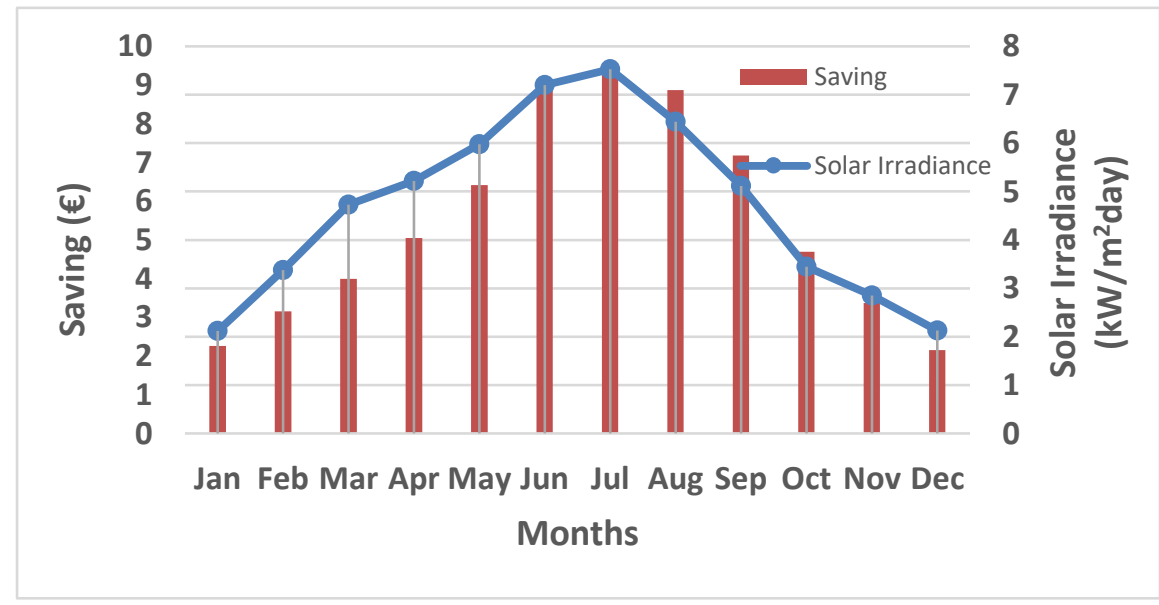

Fig 10. Monthly variation of savings (€) by average daily solar irradiance (kW/m2day)

Regarding the savings from the system, total monthly savings and monthly average solar irradiance were plotted by Fig.10. Total monthly savings $(€)$ were calculated as 6.73 ; $7.77 ; 9.61 ; 10.71 ; 11.93 ; 13.4 ; 13.77 ; 11.98 ; 10.69 ; 7.93 ; 7.27$ and 5.97 from January to December, respectively. Annual saving per module is reached as $117.83 €$. 


\section{Conclusions}

In the present study, annual performance covering electrical, overall energy and savings of PVT system integrated with natural zeolite was evaluated. Performance parameters were calculated hourly and averaged. In hourly calculations, correlations obtained from the experiments were used and real meteorological data and annual values on an hourly basis were estimated. Monthly average hourly values of energy efficiency, electrical power, overall produced energy and the savings were estimated. Remarkable results of the study could be listed as below:

- $\quad$ Average daily solar irradiance values were found as $2.11 ; 3.38 ; 4.73 ; 5.22 ; 5.98$; $7.20 ; 7.53 ; 6.44 ; 5.11 ; 3.44 ; 2.85 ; 2.13$ from January to December, respectively for Usak province where the experiments were carried out.

- Average overall energy efficiency values were found as $0.56 ; 0.54 ; 0.49 ; 0.49 ; 0.48$; $0.46 ; 0.45 ; 0.46 ; 0.50 ; 0.53 ; 0.54$ and 0.56 from January to December, respectively for natural zeolite based PVT systems. Considering that the laboratory efficiency of the PV module in the PVT system is $15 \%$, the thermal efficiency of the natural zeolite PVT is remarkable.

- Monthly average hourly produced electrical power values per module were calculated as $106.8 ; 126.7 ; 143.4 ; 148.5 ; 145.2 ; 168.6$; $161.9 ; 158.9 ; 148.2 ; 123.0$; 121.4 and $105.9 \mathrm{~W}$ from January to December, respectively.

- Monthly average overall produced energy values $(\mathrm{kWh})$ were determined as 73.93; $85.39 ; 105.59 ; 117.66 ; 131.15 ; 148.04 ; 151.35 ; 131.67 ; 117.50 ; 87.12 ; 79.90$ and 65.59 from January to December, respectively.

- Annual total overall energy produced by the PVT system integrated with natural zeolite was found as $1294.88 \mathrm{kWh}$ /year per module.

- Annual saving per module is reached as $117.83 €$ per module. With the acceptance of the system cost of $942.8 €$, simple payback period is approximately 8 years. This payback time, which is found on a single module, will surely decrease at higher installed powers.

Considering the industry, transportation and housing sectors, the highest share in energy consumption belongs to the buildings. According to research by the International Energy Agency (IEA), it has been revealed that in many IEA member countries, energy use in buildings accounts for over $40 \%$ of primary energy consumption $[19,20]$. Energy use in buildings has increased significantly over the past few decades due to population growth, economic growth and an increase in quality of life. However, as of 2019, the Covid-19 pandemic, quarantine processes and remote work applications, which have been on the agenda of the world, increase the energy consumed in the buildings far above these values. Increasing demand for energy supply has led to even faster development of low energy technologies for building applications, with global warming due to $\mathrm{CO}_{2}$ emissions from the use of non-renewable energy sources.

PVT systems based on natural zeolites could offer a very promising option to supply electrical and thermal energy demand of the building. It is hoped that this study could help to understand the performance of natural zeolite based PVT systems for building applications.

\section{Acknowledgment}

This study has been supported by The Scientific and Technological Research Council of Turkey (TUBITAK) within 214M615 research project. 


\section{References}

[1] Huang BJ, Yang PE, Lin YP, Lin BY, Chen HJ, Lai RC. Solar cell junction temperature measurement of PV module. Solar Energy, 2011; 85:388-92. https://doi.org/10.1016/j.solener.2010.11.006

[2] Kandilli C. A comparative study on the energetic- exergetic and economical performance of a photovoltaic thermal system (PVT), Research on Engineering $\begin{array}{llll}\text { Structures } \quad \text { and } & \text { Materials, }\end{array}$ https://doi.org/10.17515/resm2019.90en0117

[3] Huang MJ, Eames PC. Norton B. Phase change materials for limiting temperature rise in building-integrated photovoltaics. Solar Energy, 2006; 80, 1121-1130. https://doi.org/10.1016/i.solener.2005.10.006

[4] Huang MJ, Eames PC. Norton B., Hewitt NJ. Natural convection in an internally finned phase change material heat sink for the thermal management of photovoltaics. Solar Energy Materials and Solar Cells, 2011; 95, 1598-1603. https://doi.org/10.1016/j.solmat.2011.01.008

[5] Park J, Kim T, Leigh SB. Application of a phase-change material to improve the electrical performance of vertical-building-added photovoltaics considering the annual weather conditions. Solar Energy, 2014, 105, 561-574. https://doi.org/10.1016/j.solener.2014.04.020

[6] Ho CJ, Chou WL, Lai CM. Application of a water-saturated MEPCM-PV for reducing winter chilling damage on aqua farms. Solar Energy, 2014; 108:135-145. https://doi.org/10.1016/j.solener.2014.07.006

[7] Hasan A, McCormack SJ, Huang MJ, Norton B. Characterization of phase change materials for thermal control of photovoltaics using Differential Scanning Calorimetry and Temperature History Method. Energy Conversion and Managemant;2014, 81, 322 329. https://doi.org/10.1016/i.enconman.2014.02.042

[8] Ho CJ, Tanuwijava AO, Lai CM. Thermal and electrical performance of a BIPV integrated with a microencapsulated phase change material layer. Energy and Buildings, 2012; 50:331-8. https://doi.org/10.1016/i.enbuild.2012.04.003

[9] Lin W, Ma Z, Sohel MI, Cooper P. Development and evaluation of a ceiling ventilation system enhanced by solar photovoltaic thermal collectors and phase change materials. Energy Conversion and Managemant, 2014; 88, 218-230. https://doi.org/10.1016/j.enconman.2014.08.019

[10] Gurmen Ozcelik T. Investigation of glycerol-Ni(NO3)26H2O /perlite composites as form stable phase change materials. Research on Engineering Structures and Materials, 2020; 6(2): 141-151. https://doi.org/10.17515/resm2019.122ma0221

[11] Kandilli C. Energy, exergy, and economical analyses of a photovoltaic thermal system integrated with the natural zeolites for heat management. International Journal of Energy Research. 2019;43, 4670-4685. https://doi.org/10.1002/er.4605

[12] https://www.mgm.gov.tr/veridegerlendirme/il-ve-ilceler-istatistik.aspx?m=USAK [access, 07.07.2020]

[13] Negis F. Zeolite Based Composites In Energy Storage, Izmir Institute of Technology The Graduate School, Master of Science in Materials Science and Engineering, 1999.

[14] Brottier L, Bennacer R, Thermal performance analysis of 28 PVT solar domestic hot water installations in Western Europe, Renewable Energy (2020). https://doi.org/10.18086/swc.2019.05.01

[15] Xu L, Ji J, Zhaomeng KL, Xu LT, Huang S. Annual analysis of a multi-functional BIPV/T solar wall system in typical cities of China, Energy , 2020;197:117098 https://doi.org/10.1016/i.energy.2020.117098 
[16] Gholami H, Røstvik HN. Economic analysis of BIPV systems as a building envelope material for building skins in Europe. Energy, 2020; 204: 117931 https://doi.org/10.1016/j.energy.2020.117931

[17] Duffie JA, Beckman WA. Solar Engineering of Thermal Processes, Wiley-Interscience Publication, Second Edition, 1991, pp.25-32

[18] https://www.mta.gov.tr/v3.0/bilgi-merkezi/zeolit [access, 07.07.2020]

[19] IEA. Modernising building energy codes to secure our global energy future. International Energy Agency <www.iea.org $>$ [accessed 4.11.13].

[20] https://www.ase.org/initiatives/buildings\#: :text=Energy\%20Use\%20in\%20Buildi ngs,other\%20sector\%20of\%20the\%20economy . [10.07.2020] 